\title{
German-language Popular Music Studies in Germany, Austria and Switzerland
}

\author{
Martin Pfleiderer \\ Institute for Musicology, Liszt School of Music Weimar / \\ Friedrich Schiller University Jena, Germany \\ martin.pfleiderer@hfm-weimar.de
}

\begin{abstract}
Following the foundation of IASPM in 1981, the German ASPM (Arbeitskreis Studium Populäre Musik e.V.) was established in 1984. Although there is a free dialogue with IASPM, the organizations operate independently. In Germany, Austria and Switzerland, a variety of courses are offered in popular music studies, although often by young tutors, many of whom are doctoral students, which means that the field still has some way to go to become firmly established in the academic world. In addition, German-speaking academic communities read English-language publications but few publish their research papers in English, in international journals. Nevertheless, there is no big gap between the issues of popular music research in Germany and in the predominant Anglo-American academic discourses, due to central themes concerning popular music that bridge the frontiers of nation-states and national culture, such as globalisation, world music, or performance and media studies.
\end{abstract}

Keywords:

In winter 2010/11 almost 200 courses concerning popular music were offered by university programs in Germany, Austria and Switzerland, mostly provided by musicology and music pedagogy departments. ${ }^{1}$ These courses focus on an amazing variety of issues and topics, to which I will return later. Since almost every university and music high school (Musikhochschule) offers courses filed under populäre Musik, it seems that popular music research is currently thriving in German-speaking academia. However, looking at who actually offers those courses, a more cautious picture arises; most are offered by young researchers - so-called wissenschaftliche Mitarbeiter (scientific associates) - who are working on their $\mathrm{PhD}$ or who have just finished their $\mathrm{PhD}$. There are only a few associate or senior professorships in Germany that specialize in popular music research (e.g. in Berlin, Paderborn, Cologne and Weimar), and there are no such professorships in Austria and Switzerland. Moreover, most of the musicology departments have little or no experience in popular music research, except seminal departments like those in Berlin, Giessen, Graz, Hamburg, or Oldenburg, initiated during the 1970s or 1980s to explore jazz and popular music. So, on the one hand, looking at the variety of courses that are offered, popular music research finally seems to have succeeded. On the other hand, popular music studies are far from being well established at the German, Austrian or Swiss university campus; it's still a delicate plant - a wallflower in academia. 


\section{Popular music research in Germany - late beginnings}

Generally in German-speaking countries, popular music research is assigned to departments of musicology. Therefore, it is necessary to have some understanding of the history of musicology. In the 19th century, music research in Germany was moulded by the construction of a dichotomy between high and low music, between art music of the 3-B-tradition (Bach-Beethoven-Brahms) and those genres called "light music" (Leichte Musik), "entertaining music" (Unterhaltungsmusik) or even "trivial music" (Trivialmusik). This dichotomy had already been established during the first half of the 19th century by music critics such as Robert Schumann or Franz Brendel in the Neue Zeitschrift für Musik (founded in 1834 by Schumann). At that time, it still had to be proven that art music could be as aesthetically valuable as other arts like poetry, literature or painting. Therefore, critics quickly split the two musical spheres in order to upgrade European art music as autonomous and valuable, while condemning other kinds of music as functional, spiritless (geistlos), and even morally dangerous (see Sponheuer 1980, Fuhr 2007).

Theodor W. Adorno updated this problematic dichotomy in the 20th century. He distinguished between autonomous art music that is worth being analysed and discussed, and music fabricated by the so-called "culture industry" that is only of interest because it could tell something about the social conditions of capitalism. To be precise, Adorno, who was a Professor in Frankfurt/Main from 1949 until his death in 1969, established a sociological approach to popular music that remained fruitful. However, Adorno's approach was burdened by misconceptions and degradations of what he called "popular" music and for a long time this was a stumbling block for young researchers interested in jazz and popular music. Until the 1960s and 1970s - and even in the 1980s and 1990s - musicology in Germany, Austria and German-speaking Switzerland held on to the Adornian verdicts about popular music. Admittedly, there was some new research on popular music in the 19th century, for example by seminal musicologist Carl Dahlhaus as early as in the 1960s; however, Dahlhaus still advocated the term "trivial music" (Trivialmusik) (Dahlhaus 1967).

Changes in attitudes towards popular music and its appreciation as an issue of serious academic interest came from systematic musicology, music pedagogy and jazz research. While mainstream musicology was still looking for building on the monuments of German art music (Denkmäler Deutscher Tonkunst), in systematic musicology (another wallflower in German academia), a more value-free approach to popular music culture developed. At Hamburg University for instance, during the late 1960s, several systematic musicologists developed an approach to music in popular and youth culture from psychological and sociological points of view. In Vienna (Austria) Kurt Blaukopf followed a concept of music sociology that encompasses research on media, youth and popular music. ${ }^{2}$ In general, music psychology and music sociology advanced popular music research in German-speaking academic communities. The field of ethnomusicology in Germany was not as extensive as in the USA or Great Britain, since many ethnomusicologists, such as Erich von Hornbostel, Curt Sachs or George Herzog, emigrated when the Nazis took over during the 1930s.

In the late 1950s the triumphal procession of rock and roll reached Europe, shortly after its success in the United States, and in the 1960s beat and rock flooded the German-speaking youth market. Moreover, in the late 1960s the (West-)German record industry started to expand, mainly due to sales of popular music. Music education responded to these developments, although slowly at first. During the 1960s, there were single conferences, for example, on the impact of technological mediation upon music education, but since the 1970s many publications addressed issues such as popular music in the classroom (Roesing 2003).

Jazz was a different story. The International Institute for Jazz Research in Graz, Austria, was founded in 1967, and during the 1970s and 1980s programmes for jazz musicians were organised at almost every music high school in Germany. Popular 
music training, in contrast, still existed at the margins of these jazz departments with only a few exceptions, such as the Kontaktstudiengang Popularmusik in Hamburg since 1982, or the Popakademie Baden-Württemberg in Mannheim since 2003. In recent years, however, some jazz departments at music high schools have been renamed as "jazz and popular music" (Jazz und populäre Musik).

\section{"A change is gonna come" - the breakup of the 1980s}

Serious research on popular music in German-speaking countries began during the 1970s, assisted by the publication of several books. For example, three music journalists at Radio Bremen initiated a long broadcast series about the history of popular music until the Second World War that was also published as a book (Kuhnke, Miller, Schulze 1976); this series continued into the 1980s. The documents and sources of this research project laid the ground for the collection of one of the largest archives of jazz and popular music in Germany, the Klaus-Kuhnke-Archives in Bremen. $^{3}$ In 1977, Rowohlt - one of the major German paperback publishers introduced the book series Rock Session, which compiled articles of international popular music journalists and researchers followed by German translations of the new wave of Anglo-American popular music research, including Simon Frith's Sound Effects--Youth, Leisure and the Politics of Rock ' $n$ ' Roll (Frith 1981) and Steve Chapple's and Reebee Garofalo's Rock 'n' Roll is Here to Pay (Chapel/Garofalo 1980).

In 1983, the Center for Popular Music Research (Forschungszentrum Populäre Musik) was founded at Humboldt University in the eastern part of Berlin. ${ }^{4}$ Since the 1980s, Peter Wicke has been engaged there in critical research on popular music predominantly from a sociological perspective. One of Wicke's merits for popular music research in Germany is the early reception of British and American cultural studies and cultural theory culminating in collaboration with authors such as John Shepherd (Shepherd/Wicke 1997). After the fall of the inner German borderline in 1989, a Chair of Popular Music History and Theory was initiated as part of the Institute for Musicology at Humboldt University. Since 1992, the research magazine PopScriptum has been published there as well, at first in print, followed by an online version. ${ }^{5}$

Following the foundation of IASPM in 1981, the German ASPM (Arbeitskreis Studium Populäre Musik e.V.) was established in 1984. ASPM almost immediately started to organize annual conferences on popular music research and to publish the annual Beiträge zur Popularmusikforschung (contributions to popular music research, since 1986) as well as several book series. ${ }^{6}$ ASPM is currently a large and wellestablished organisation for popular music research with almost 200 members in Germany, Austria and Switzerland. ${ }^{7}$ In addition, during 2010 and 2011 ASPM invited English and American researchers, including Allan Moore, Simon Frith and Walter Everett, to conferences and summer schools in Germany.

Since the late 1990s, the number of $\mathrm{PhD}$ and research projects associated with popular music has been growing continuously, especially in Germany. Each year, several conferences dedicated to issues of popular music research take place and several dozens of books are published. A new generation of students and young researchers, born under the auspices of rock, pop, soul, punk, techno, and rap music, created an urgent demand for popular music courses and programs at universities. More and more musicologists initially trained in European music history, now conduct research and offers popular music courses, too. However, the academic scene is changing more slowly in musicology departments, while in sociology and media studies departments, the exploration of popular culture is welcomed. Since the 1990s the growth of media studies (Medienwissenschaft), rooted in German literary studies, can be called a success story in German-speaking countries, and research interests in various phenomena of popular media culture is expanding within this field of study. However, popular music research still remains at the margins of large departments of 
sociology and media studies. At least, after the turn of the century, the Bachelor and Masters program, Popular Music and Media, was launched at Paderborn University. More recently, some universities are now offering Masters programs with a strong emphasis on popular music research, such as in Gießen and Weimar.

\section{Issues of popular music research in German-speaking countries}

It is not an easy task to give a complete and valid overview of research topics in German-speaking countries. The areas of popular music research are manifold - too many to be mapped out in detail here. There is still a lot of discussion about Adorno's "cultural industry" theory; on subcultures and music scenes of young people; about British cultural studies and German Kulturwissenschaften. More recently, research of live performances, mediated "liveness", and audiovisual construction of star images has also come to the fore. There are new emphases on issues of popular music analysis and aesthetics, the two often combined, and on the study of mediated sound and sonic culture.

Although there is no reliable database for conferences and academic publications on popular music, a vivid picture of popular music studies can be provided from listings of university courses in Germany, Austria, and Switzerland from summer 2007 until winter 2010/11 that are available on the homepage of ASPM. ${ }^{8}$ The range of titles of university courses give clues to the main areas of interest and research of students, lectures and researchers in German-speaking countries. To return our attention to courses offered in winter 2010/11, course titles can be organized into four thematic categories: firstly, 76 courses focus on histories of popular music in general or on particular genres or artists; secondly, about 21 courses address theories and methodological issues, such as music analysis, in popular music research; thirdly, 50 courses focus on the economies, technologies and mediation of popular music, including journalism and film; finally, the remaining 46 courses focus on various systematic aspects, such as gender, ethnicity, youth, music reception, or improvisation, or on specific topics like the phenomenon of the "comeback" or of popular music in big cities. The assignment of the courses to these four categories is plotted in Figure 1.

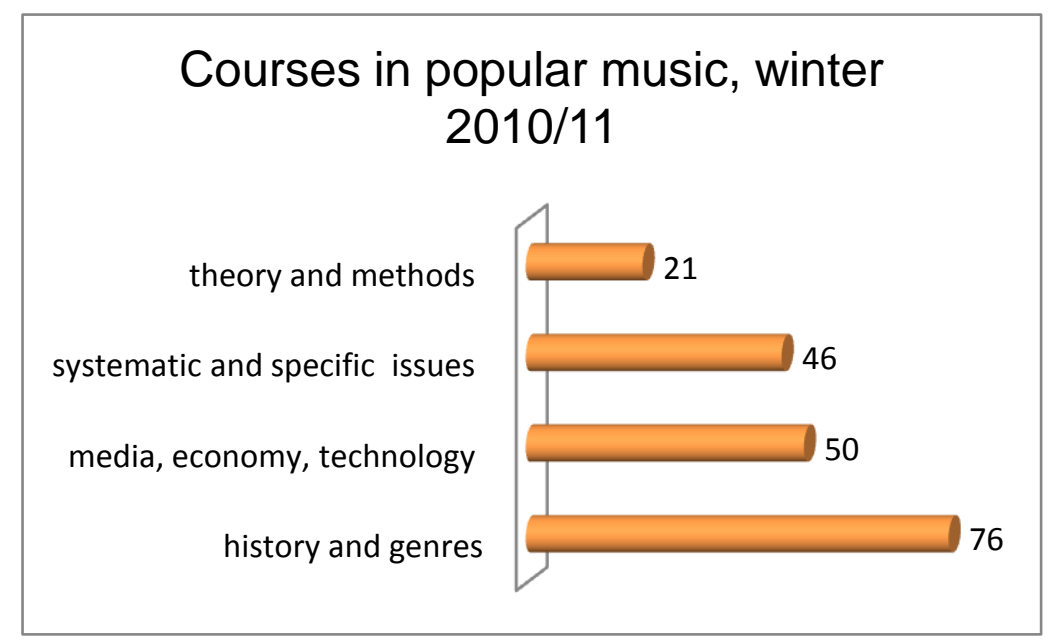

Figure 1 - 193 courses in popular music at 67 universities or music high schools in German-speaking countries, winter 2010/11, assigned to four areas of research.

Astonishingly, an interest in issues specific to popular music in Germany, Austria or Switzerland in the past and present seems not as large as may be expected. There is research on the German Schlager and on Austro-pop; on the history of 
popular music in the 19th century, in the Weimar republic (1919-33) and during the Nazi regime (1933-45); on German New Wave (Neue Deutsche Welle) around 1980; on rock in the German Democratic Republic; and on rap music and electronic dance music made in Germany, Austria and Switzerland. German history has also given cause to continuous research attention to right wing music scenes in Germany (although such scenes are not at all a uniquely German phenomenon).

To sum up, as far as I can see there is no big gap between the issues of popular music research in Germany and in the predominant Anglo-American academic discourses. It seems that central themes concerning popular music are bridging the frontiers of nation-states and national culture - for example, the global dissemination of popular music, world music, or performance and media studies. Unfortunately, where it concerns language and national traditions, popular music research is still a one waystreet: German-speaking academic communities read English-language publications but few Germans publish their research papers in English, in international journals like Popular Music, or visit international conferences regularly. Perhaps this will change in the near future. In my opinion, popular music research in German-speaking countries is of worldwide interest and therefore the mono-lingual, one-way street has to be broken up. Since English is the international currency, it is rather improbable that many researchers in the United States, the United Kingdom, or Japan will start learning German; this self-imposed barrier has to be broken up by Germans, Austrians and Swiss' themselves.

\section{Endnotes}

1. Exactly 193 courses at universities and music high schools (Musikhochschulen) or music universities are listed at the homepage of ASPM, see http://aspm.ni.lo-net2.de/info/lehrveranstaltungen/wise201011.html (consulted 10.nov.2011). Data for summer 2011 or winter 2011/2012 are not yet available.

2. In 1969 Mediacult - International Research Institute for Media, Communication and Cultural Development was founded in Vienna by Blaukopf and others, see http://www.mediacult.at/en/main.html (consulted 10.nov.2011).

3. See http://www.kkarchiv.de/ (consulted 10.nov.2011). The other big archives in Germany are Deutsches Volksliedarchiv - Institut für Internationale Popularliedforschung in Freiburg. http://www.dva.uni-freiburg.de/ (consulted 10.nov.2011), Jazzinstitut Darmstadt, http://www.jazzinstitut.de/ (consulted 10.nov.2011) and Lippmann+Rau-Music Archives in Eisenach, http://www.Irmusikarchiv.de/ (consulted 10.nov..2011). Each of these archives owns several ten thousands of records, books, magazines and photographs concerning jazz, blues, popular music, folk music etc.

4. See http://www2.hu-berlin.de/fpm/mainpage e.html (consulted 10.nov.2011).

5. See http://www2.hu-berlin.de/fpm/popscrip/index.htm (consulted 10.nov.2011).

6. See http://aspm.ni.lo-net2.de/info/publikationen.html (consulted 10.nov.2011).

7. Although German ASPM is not an official IASPM branch, many ASPM members are members of the IASPM, too. There is no rivalry but a growing cooperation between the two organisations.

8. See http://aspm.ni.lo-net2.de/info/lehrveranstaltungen.html (consulted 10.nov. 2011); there are also data concerning summer 2006 and winter 2006, but since they have been compiled differently they are less encompassing and less valid. 


\section{References}

Chapple, Steve and Garofalo, Reebee. 1980. Wem gehört die Rock Musik? Geschichte und Politik der Musikindustrie. Rowohlt, Reinbek.

Dahlhaus, Carl (ed.). 1967. Studien zur Trivialmusik des 19. Jahrhunderts. Bosse, Regensburg.

Frith, Simon. 1981. Jugendkultur und Rockmusik. Soziologie der englischen Musikszene, Rowohlt, Reinbek.

Fuhr, Michael. 2007. Populäre Musik und Ästhetik. Die historisch-philosophische Rekonstruktion einer Geringschätzung, Transkript, Bielefeld.

Kuhnke, Klaus; Miller, Manfred and Schulze, Peter. 1976. Geschichte der Pop-Musik. Band 1 (Bis 1947), new edition of "Roll over Beethoven", Eres-Edition, Lilienthal b., Bremen.

Rösing, Helmut. 2002. "'Popularmusikforschung' in Deutschland - von den Anfängen bis zu den 1990er Jahren" In Musikwissenschaft und populäre Musik. Versuch einer Bestandsaufnahme (= Hamburger Jahrbuch für Musikwissenschaft, Bd. 19), ed. Helmut Rösing, Albrecht Schneider, and Martin Pfleiderer, Peter Lang, Frankfurt, p.1335.

Shepherd, John and Wicke, Peter. 1997. Music and Cultural Theory. Polity Press, Cambridge.

Sponheuer, Bernd. 1980. "Zur ästhetischen Dichotomie als Denkform in der ersten Hälfte des 19. Jahrhunderts. Eine historische Skizze am Beispiel Schumanns, Brendels und Hanslincks." In Archiv für Musikwissenschaft, 37: pp. 1-31. 